\title{
Concurrent Expression and Regulation of Genes Involved in Carbon and Nitrogen Metabolism in Relation with Nitrogen Use Efficiency
}

\author{
Anamika Kashyap $^{1 *}$, Arnab Saha ${ }^{1}$, I.N. Sanyal ${ }^{2}$ and B.R. Singh ${ }^{1}$ \\ ${ }^{1}$ Department of Molecular Biology and Genetic Engineering, College of Basic Science and \\ Humanities, Govind Ballabh Pant University of Agriculture and Technology, \\ Pantnagar- 263145 (India) \\ ${ }^{2}$ Plant Transgenic Lab, CSIR-National Botanical Research Institute, P.O. Box 436, Rana \\ Pratap Marg, Lucknow 226 001, India \\ *Corresponding author
}

\begin{tabular}{|c|c|}
\hline & B \\
\hline Keywo & \multirow{7}{*}{$\begin{array}{l}\text { Nitrogen use efficiency (NUE) for the crop plants is of great concerns throughout the } \\
\text { world. The burgeoning population of the world needs crop genotypes responding to } \\
\text { higher nitrogen and showing a direct relationship to yield with the use of nitrogen } \\
\text { inputs i.e. high nitrogen-responsive genotypes. However, for fulfilling the high global } \\
\text { demand of organic produce, it requires the development of low nitrogen-responsive } \\
\text { genotypes with greater nitrogen use efficiency and grain yields. Nitrogen is the most } \\
\text { important inorganic nutrient for plant growth. Its effects have been directed to } \\
\text { understand the molecular basis of plant responses to nitrogen and to identify nitrogen- } \\
\text { responsive genes in order to manipulate their expression and enable the plant to use } \\
\text { nitrogen more efficiently. Nitrogen use efficient crops can be produced by } \\
\text { manipulating the genes existing in pathways relating to nitrogen uptake, assimilation, } \\
\text { amino acid biosynthesis, C/N storage and metabolism, signaling and regulation of } \\
\text { nitrogen metabolism and translocation, remobilization and senescence. }\end{array}$} \\
\hline & \\
\hline & \\
\hline $\begin{array}{l}\mathrm{C} / \mathrm{N} \text { storage and } \\
\text { metabolism, }\end{array}$ & \\
\hline & \\
\hline Article Info & \\
\hline $\begin{array}{l}\text { Accepted: } \\
\text { 15 June } 2018 \\
\text { Available Online: } \\
10 \text { July } 2018\end{array}$ & \\
\hline
\end{tabular}

\section{Introduction}

Nitrogen $(\mathrm{N})$ is one of the crucial plant macronutrients and required in greatest amount than all another mineral element. It comprises 1.5-2.0 percent of plant dry matter and approximately 16 percent of total plant protein (Frink et al., 1999). Even healthy plants contain 3 to 4 percent nitrogen in their above-ground tissues.
Different plant genotypes of a species sense and respond differentially to the available $\mathrm{N}$ in the soil giving rise to differential $\mathrm{N}$ responsiveness which is an important agricultural trait. Most of the high yielding varieties of the major crops developed in the last several decades have high demands of $\mathrm{N}$ and other nutrients, as well as optimal cultivation conditions (Socolow, 1999). 
Nitrogen is most widely used important mineral nutrient, responsible for plant growth and biomass production, synthesis of amino acids, nucleic acids, proteins, lipids, chlorophyll, and various other N-containing compounds (Kusano et al., 2011).

The purpose of this review article is to understand the molecular aspects expression and regulation of genes involved in carbon and nitrogen metabolism with respect to $\mathrm{N}$ uptake, assimilation and transportation to different parts and the areas for increasing NUE through frontier science.

\section{Nitrogen use efficiency}

Nitrogen use efficiency (NUE) is defined as grain yield obtained per unit of applied or available nitrogen in the soil. NUE was also defined as the product of nitrogen uptake efficiency (NUPE) and nitrogen utilization efficiency (NUTE) (Moll et al., 1982). It mainly helps in the quantification of apparent Nitrogen recovery using physiological and agronomic parameters (Lochab et al., 2007). NUPE [\%] can be delineated as all $\mathrm{N}$ present in biomass at maturity divided by the sum of the $\mathrm{N}$ applied as fertilizer and Nitrogen present in soil ie. available Nitrogen and NUTE is a ratio of grain yield (in $\mathrm{kg}$ ) to total $\mathrm{N}$ uptake in biomass (NUP in $\mathrm{kg}$ ). Nitrogen uptake efficiency can be improved through split applications of fertilizers, other nutrient management, and crop management practices thereby minimizing fertilizer losses. The most suitable way to asses NUE depends on the crop, its harvest product and the processes involved in it. But the Nitrogen Utilization Efficiency could only be tackled biologically for higher productivity (Abrol et al., 1999) that includes a balance between storage and current use at the cellular and whole plant level.

NUE $=$ NUPE $\times$ NUTE
$\mathrm{NUPE}=\underline{\mathrm{N} \text { present in biomass at maturity }}$

$$
\text { Fertilizer N + Soil N }
$$

NUTE $=\underline{\text { Grain yield }}$

$$
\text { Total } \mathrm{N} \text { in biomass }
$$

\section{The fate of nitrogen in the plant}

Irrespective of the source of organic or inorganic $\mathrm{N}$ provided to the plant, the principal source of $\mathrm{N}$ is Nitrate for most crops and wild species, (Salsac et al., 1987; Näsholm et al., 2009), which is taken up by means of specific transporters (high and low affinity) located in the cell membrane of root cells (Miller et al., 2007; Dechorgnat et al., 2011). After the uptake of nitrogen in the form of Nitrate, it is then reduced to form Nitrite with the help of nitrate reductase enzyme (NR; EC 1.6.6.1), (Kaiser et al., 2011). Nitrate Reductase was the first substrate induction system seen in plants (Tang and $\mathrm{Wu}, 1957$ ). Nitrite is further gets reduced to form ammonia catalyzed by the nitrite reductase enzyme (Nir; EC 1.7.7.1) (Sétif et al., 2009). Exceptions to this pathway are also present which under circumstantial environments, ammonia transporters in roots (Ludewig et al., 2007) can facilitate a direct uptake of ammonia, if available in the soil, an example in paddy fields of rice or in acidic forest habitats (Mae et al., 1997). Ammonia can also be produced inside the plant by an array of metabolic pathways such as phenylpropanoid metabolism, photorespiration, amino acids catabolism and utilization of $\mathrm{N}$ transport compounds. Another important source of $\mathrm{N}$ is symbiotically fixed $\mathrm{N}$ which is readily available to herbaceous woody or plants species that forms a symbiotic relationship with $\mathrm{N}$ fixing microorganisms (Hirel et al., 2011). Some plants to a lesser extent use proteins, peptides or amino acids as a source of Nitrogen under low Nitrogen conditions (Good et al., 2007; Rentsch et al., 2007; Nasholm et al., 2009). Few types of research 
have been done on the uptake of organic $\mathrm{N}$ by crops like corn (Biernath et al., 2008), clover (Nasholm et al., 2000) and wheat (Nasholm et al., 2001) under organic farming conditions but the importance and significance have not been yet established. Plants growing on mature forests or arctic tundra (low $\mathrm{pH}$ and reduce soils) take up Ammonium or amino acids as a source of Nitrogen although plants adapted to aerobic soils prefer Nitrate (Maathius, 2009).

\section{Optimum nitrate uptake: Preeminent requirement fir nitrogen use efficiency}

This process occurs at the root level and two nitrate transporters coexist in plants to act coordinately to take up nitrate from the soil and allow its distribution in the whole plant (Daniel-Vedele et al., 1998).

Two nitrate transport systems have been shown to coexist in plants and to act coordinately to take up nitrate from the soil solution and distribute nitrate within the whole plant (Masclaux-Daubresse et al., 2010).

This transporter system can be divided into two types, Firstly, The low-affinity transport system (LATS) is used when nitrate is present at a higher concentration ie., above $1 \mathrm{mM}$. Secondly, the high-affinity transport system (HATS) works at low concentrations nitrates (1 $\mu \mathrm{M}-1 \mathrm{mM})$. Among the two transporters, LATS is constitutively expressed and act as a signal molecule to induce the expression of HATS and nitrate assimilatory genes (Pathak et al., 2008). There are mainly two types of HATS namely inducible High-Affinity Transport System (or iHATS) which is strongly induced in presence of nitrate while the second High-Affinity Transport System is constitutively expressed.

$\mathrm{Km}$ values of iHATS, cHATS, and LHATS for nitrate are in the ranges of 13-79uM, 6-
20uM and >1mM respectively. Nitrate transport through LATS is mediated by the NRT1 gene family. NRT1.1, which is a dual transporter participating in both low and highaffinity $\mathrm{NO}^{3-}$ uptake is an exception of this family. (Wang et al., 1998). iHATS is a multicomponent system of NRT2 family partly encoded genes or nitrate-nitrite porter family of transporters. The HATS relies on the activity of the NRT2 family (Miller et al., 2001) when the $\mathrm{NO}^{3-}$ concentration in the external medium is low. Other ion transport systems such as phosphates, sulfates etc. cannot act as a regulator for its own uptake while the nitrate does. If the cells are exposed to prolonged nitrate content, a lag period of 0.5 to 1.5 hours can be seen followed by increasing uptake capacity and finally reaches to a new steady state after 4 to 6 hours (Figure $1)$.

For transport of ammonia, both HATS and LATS are found in plant roots for its uptake (Glass et al., 2002). HATS, a saturable transport system for $\mathrm{NH}^{4+}$ uptake, is operated only when the concentration of $\mathrm{NH}^{4}{ }^{+}$is present in less than $0.5 \mathrm{mM}$ (Marschner, 2012). Physiological and ammonium influx studies were carried out on single, double, triple and quadruple mutants in order to develop the function of each of the AMT. It is mainly obtained through T-DNA insertion or by complementing the quadruple mutant by single genes (Yuan et al., 2007). Among different AMTs, AMT 1.1 and AMT 1.3 have similar $\mathrm{NH}^{4+}$ uptake capacity of around 30$35 \%$ while AMT 1.2 contributes $18-25 \%$. AMT 1.5 is having a low $\mathrm{Km}$ of $4.5 \mathrm{mM}$ with a low uptake capacity.

\section{Genes involved in Nitrogen assimilation}

A small portion of nitrate that is taken up by the roots is assimilated in the roots itself, but the larger part is transported to the shoot. In the shoot, NAD/NADP dependent nitrate is 
reduced to reductase (NR) in the cytoplasm (Meyer and Stitt, 2001). NR is mainly thought to be localized in the cytosol, although the association with the plasma membrane is seen on corn roots and barley (Ward et al., 1989). It is a homodimer where each monomer associated with a 3 prosthetic groups FAD, Haem, and Molybdenum cofactor. Characterization and identification of genes have ben done of NR in different species since 1993 (Reviewed by Meyer and Stitt, 2001). There are mainly two classes of genes namely Nia genes encoding NR apoenzyme and Cnx genes encoding Molybdenum Cobalt (Mo-Co) cofactor. Increase in NR gene expression did not improve NUE of cereal crops under low Nitrogen conditions (Good et al., 2007). Although patents have been issued utilizing NR genes from red algae showed increased maize yield under limiting Nitrogen conditions (Loussaert et al., 2011). nitrite by nitrate. (Figure. 2)

The ultimate source of inorganic $\mathrm{N}$ available to the plant is ammonium, which is incorporated into organic molecules in the form of Glutamine and Glutamate through the combined action of the two enzymes $G S$ and GOGAT. Carbon originating from photosynthesis through the tricarboxylic acid cycle (TCA cycle) provides the $\alpha-$ ketoglutarate needed for the reaction catalyzed by the enzyme GOGAT. Amino acids are further used for the synthesis of proteins, nucleotides and all $\mathrm{N}$-containing molecules (Hirel et al., 2011).

In higher plants, two forms of protein are representing the glutamine synthetase (GS)Cytosolic and Plastidic forms. (Hirel B et al., 1993) Decameric structure of Maize GS was described by Unno et al., 2006. Studies on both monocot and dicot plant species showed that cytosolic GS (GS1) is encoded by complex GLN1 gen family (Lam H-M et al., 1995). It mainly involves in ammonium recycling during development stages such as leaf senescence and also in Glutamine synthesis for transports it to phloem sap (reviewed by Bernard and Habash, 2009). Whereas, plastidic GS2 is encoded by single nuclear gene GLN2. It is thought to be involved in assimilation of $\mathrm{NH}_{4}{ }^{+}$coming from nitrate reduction in both $\mathrm{C}_{3}$ and $\mathrm{C}_{4}$ plants (Keys et al., 1978).. The GS fixes ammonium with glutamate to form glutamine which reacts with 2-oxoglutarate to form 2 molecules of Glutamate. The latter reaction is catalyzed by Glutamine-2-oxoglutarate aminotransferase (or Glutamate synthase, GOGAT). 2 forms of Glutamate synthase are present namely FdGOGAT and NADH-GOGAT which uses Fd and $\mathrm{NADH}$ as the electron donor respectively (Vanoni et al., 2005). Fd-GOGAT is primarily found on leaf chloroplast whereas NADHGOGAT predominantly located in plastids of nonphotosynthetic tissues such as roots, companion cells. Structures, properties, regulatory mechanism and role in amino acid metabolism by this enzyme was reviewed by Suzuki and Knaff (2005). Cross genomeortho-meta-QTL studies in cereals identified GOGAT genes, assuming that it may be a major candidate for cereal NUE (Vitousek et al., 2009). In primary assimilation of ammonia, prevailing GS/GOGAT isoenzymes are chloroplastic GS2 and Fd-GOGAT and cytosolic GS1 and NADH-GOGAT (Lam et al., 1998). Secondary assimilation of ammonia is executed by its incorporation in glutamine/glutamate amino acids using carbon-containing intermediates which are produced via metabolic pathways. Three enzymes participate in this reaction namelyCytosolic Asparagine Synthetase (AS), Plastidic Carbamoyl phosphate synthase (CPSase) and Mitochondrial NADHGlutamate dehydrogenase (NADH-GDH). AS transfers the amido group of Glutamine to aspartate to form glutamate and asparagines in an ATP catalyzed reaction (Lam et al., 2003). Asparagine has higher N/C ratio than 
Glutamine. So it can be used as a long storage compound and for long-range transport in case of legumes (Rochat and Boutin, 1991; Lam et al., 2003).Small gene family encodes AS in case of higher plants (Lam H-M et al., 1998). While in Arabidopsis it is mainly encoded by three genes (ASN1, ASN2, ASN3). Overexpressing ASN1 using constitutive promoter causes enhanced soluble seed protein content, total protein content and better growth on $\mathrm{N}$ limiting medium(Lam $\mathrm{H}-$ $\mathrm{M}$ et al., 2003). While ASN2 gene overexpression effects less endogenous ammonium compared to wild-type plant on $50 \mathrm{mM} \mathrm{Nh}_{4}{ }^{+}$medium (Lam H-M et al., 2003). $\mathrm{NADH}-\mathrm{GDH}$ incorporate $\mathrm{NH}^{+}$to 2oxoglutarate to form glutamate to a high level of $\mathrm{NH}_{4}^{+}$under stress condition (Skopelitis et al., 2006). It is the main enzyme involved in inorganic $\mathrm{N}$ assimilation in plants (Lea et al., 2011). The physiological role of GDH has not yet fully understood (Dubois F et al.,2003). But a number of experiments using ${ }^{15} \mathrm{~N}$ labeling followed by GCMS or NMR spectroscopy showed that it helps in glutamate deamination to provide organic acids in Climited conditions (Aubert et al., 2011; Labboun et al., 2009) although the rate is far lower than GS-GOGAT pathway (Skopelitis et al., 2006). GDH activity in $\mathrm{N}$ management and in whole plant physiological properties has been done on Tobacco (Terce-Laforgue et al., 2004) and Maize (Hirel et al., 2005)

\section{Genes involved in Transport of Nitrogen and its remobilization}

During senescence, leaf proteins, particularly photosynthetic proteins of plastids are extensively degraded, provides an enormous source of nitrogen to plant. Plants can use this nitrogen as a supplement of nutrition to grow organs such as new leaves and seeds. (Figure. 3) In oilseed rape and Arabidopsis, it has been shown that nitrogen can be remobilized from senescing leaves to seeds at the reproductive stage as well as from senescing leaves to expanding leaves at the vegetative stage (Lemaitre et al., 2008). At the reproductive stage experiments of ${ }^{15} \mathrm{~N}$ tracing showed that the rate of nitrogen remobilization from the rosettes to the seeds and to the flowering organs was similar in early and late senescing lines (Diaz et al., 2008).

Some studies in maize, wheat, and barley show that grain nitrogen content is correlated with flag leaf senescence. It shows that flag leaf senescence plays a special role in nitrogen availability for grain filling. For NRE, the onset and the speed of flag leaf senescence are essential (Uauy et al., 2006). Delaying leaf senescence results in increases grain yield and carbon filling in seeds due to the prolongation of photosynthesis but it also responsible for decreasing protein content.

During senescence chloroplasts show the first symptoms of deterioration, whereas other organelles are degraded later, the mechanisms involve for chloroplast degradation are unclear. Chloroplasts contain a high number of proteases like DegP, FstH proteases, and FstH6 protease that responsible for degradation of chloroplast proteins within the organelle during. In senescence, DegP and FstH proteases degrade D1 protein and FstH6 protease degrade LHCII protein (Martinez et al., 2008).

\section{Genes for Carbon Metabolism}

The ability of the plant to take up and bestow nitrogen cannot result in increased nitrogen use efficiency alone. The other important aspect to be considered for increasing NUE is the link between $\mathrm{C}$ and $\mathrm{N}$. If there is the insufficient availability of carbon, plants capability to utilize $\mathrm{N}$ can be compromised and vise versa (Reich et al., 2006). For example, upregulation of nitrate transporters (AtNRT2.1 and At NRT1.1) was related to 
Glucose-6-Phosphate concentration (Wirth et al., 2007). In spite of this, it was shown that increase in nitrate supply causes a decrease of starch synthesis and produces more amino acids from organic acids through carbon diversion. On the other hand, nitrate deficiency causes a decrease in many amino acids along with increasing carbohydrates, phosphoesters and secondary metabolites (Fernie t al., 2004). Studies on global gene expression showed that nitrate responsive gene required the presence of both $\mathrm{N}$ and sugar, with carbon modulating effect and vice versa (Price et al., 2004). Nitrogen is stored in large quantities in photosynthetic proteins such as Rubisco and phosphoenolpyruvate carboxylase (PEPc); also crucial to plant $\mathrm{C}: \mathrm{N}$ ratios are the products of the GS-GOGAT assimilatory pathway. Overexpressing Rubisco (rbcs) gene in a rice plant showed increase rubisco-N to leaf- $\mathrm{N}$ although there was no change in photosynthesis (Suzuki et al., 2007). Using native PEPc promoter to overexpress PEPc gene showed increasing PEPc transcript level but photosynthetic rates were limited by phosphate $(\mathrm{Ku}$ et al., 1999; Hausler et al., 2002). PEPc involved in $\mathrm{N}$ metabolism but not play a direct role in NUE (Figure 4).

Photosynthetic rate controls $\mathrm{N}$ uptake and assimilation as well as remobilization (Zheng 1996), thus leading to a plateau in NUE unless the photosynthetic rate is also increased. Photosynthetic Nitrogen Use Efficiency (PNUE) is calculated by the rate of carbon assimilation per unit leaf nitrogen (Kumar et al., 2001). $\mathrm{C}_{4}$ plants have a greater PNUE than $\mathrm{C}_{3}$ plants, owing to the $\mathrm{C}_{4}$ concentrating mechanism that leads to $\mathrm{CO}_{2}$ saturation of Rubisco. Further evaluation of the key components of photosynthesis and interactions of $\mathrm{C} / \mathrm{N}$ metabolites might offer avenues for improving $\mathrm{N}$ utilization by optimizing $\mathrm{N}$ content in respect to photosynthetic demand.

\section{Transcription factors and other regulatory proteins}

Nitrate is not only a nutrient but also a signal for the regulation of hundreds of nitrateresponsive genes, which include $\mathrm{N}$ and $\mathrm{C}$ metabolizing enzymes, redox enzymes and a whole range of signaling proteins and transcription factors.

The transcriptional regulation of nitrateresponsive genes could involve cis-acting regulatory sequences or nitrate response elements (NRE) (Raghuram et al., 2006). Identification of such regulatory elements might provide an end-point for nitrate signaling and open up avenues for characterizing/manipulating the rest of the signaling pathway to enhance NUE.

Transcription factors (TFs) are master regulators that coordinate the expression of entire response networks of target genes and a number of attempts have been made to identify TFs that regulate nitrate-responsive gene expression. Dof1, a plant-specific transcription factor, is involved in the activation of non-photosynthetic, C4-related PEPc, as well as other organic acid metabolism proteins, and is up-regulated during drought stress. Dof1 over-expressing rice and Arabidopsis showed increased induction of the gene encoding PEPc.

When Dof1 over-expressing rice lines were grown in $\mathrm{N}$ deficient conditions, both the $\mathrm{N}$ and $\mathrm{C}$ amounts in the seedlings were increased. Transgenic plants also showed increases in root $\mathrm{N}$, root biomass, and rate of photosynthesis under $\mathrm{N}$ limiting condition (Kurai et al., 2011). More experimentation, particularly field trials, is necessary for relation to Dof1 and its role in NUE (Figure. $5)$. 
Figure.1 Schematic presentation of the known localisation of NRT1, NRT2 and AMT genes in Arabidopsis

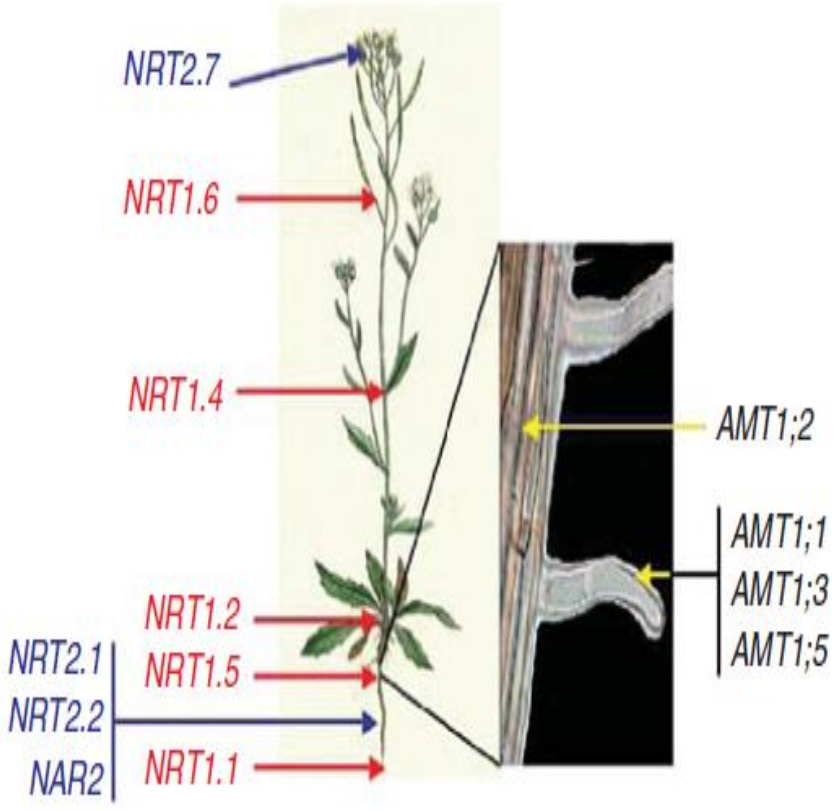

Figure.2 Main reactions involved in nitrogen assimilation in higher plants. $\mathrm{NO}_{3}{ }^{-}=$nitrate; $\mathrm{NO}_{2}{ }^{-}$ $=$ nitrite; $\mathrm{NH}_{4}{ }^{+}=$ammonium, $\mathrm{N}_{2}=$ atmospheric dinitrogen. The main enzymes involved in nitrate reduction and ammonia assimilation are indicated in italics: $N R=$ nitrate reductase; $N i R=$ nitrite reductase; Nase = nitrogenase; $G S=$ glutamine synthetase; $G O G A T=$ glutamate synthase

\section{Sources of organic and inorganic $\mathrm{N}$}

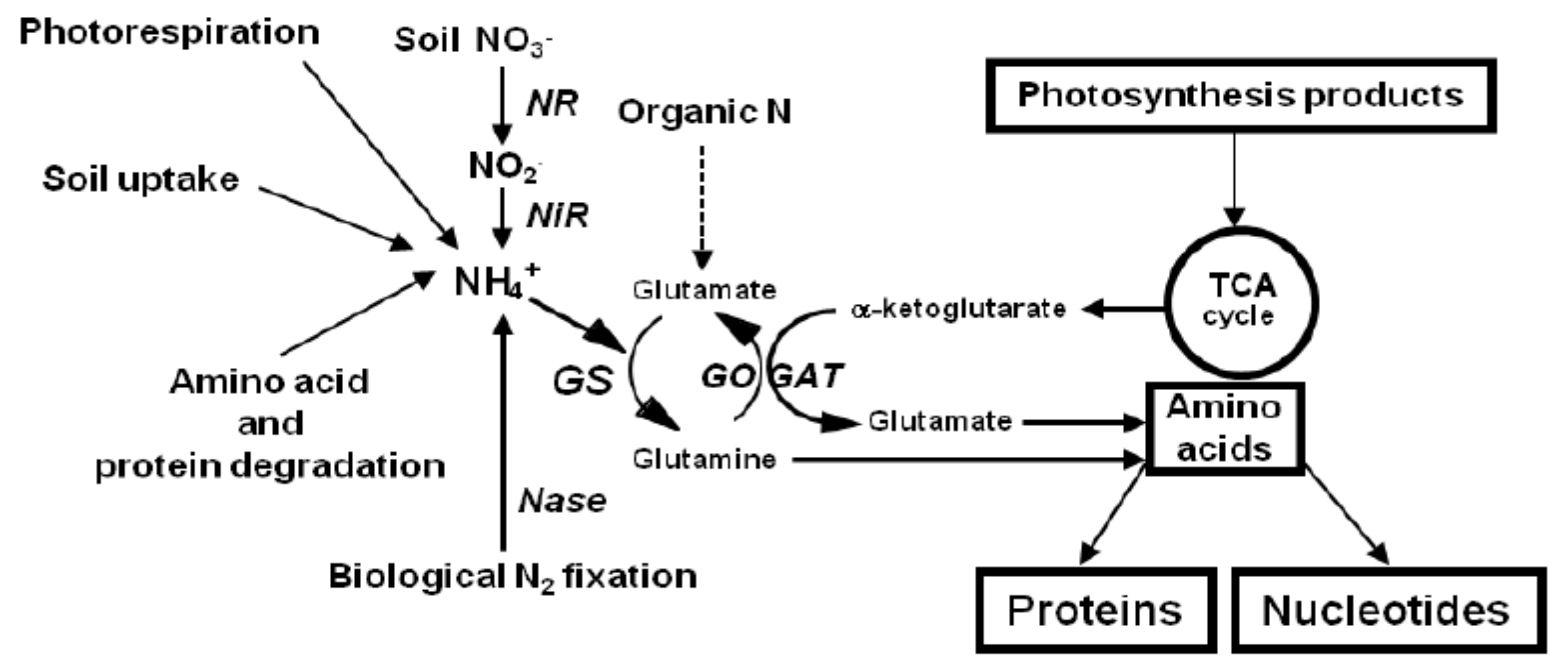


Figure.3 Schematic representation of nitrate transport steps within the plant

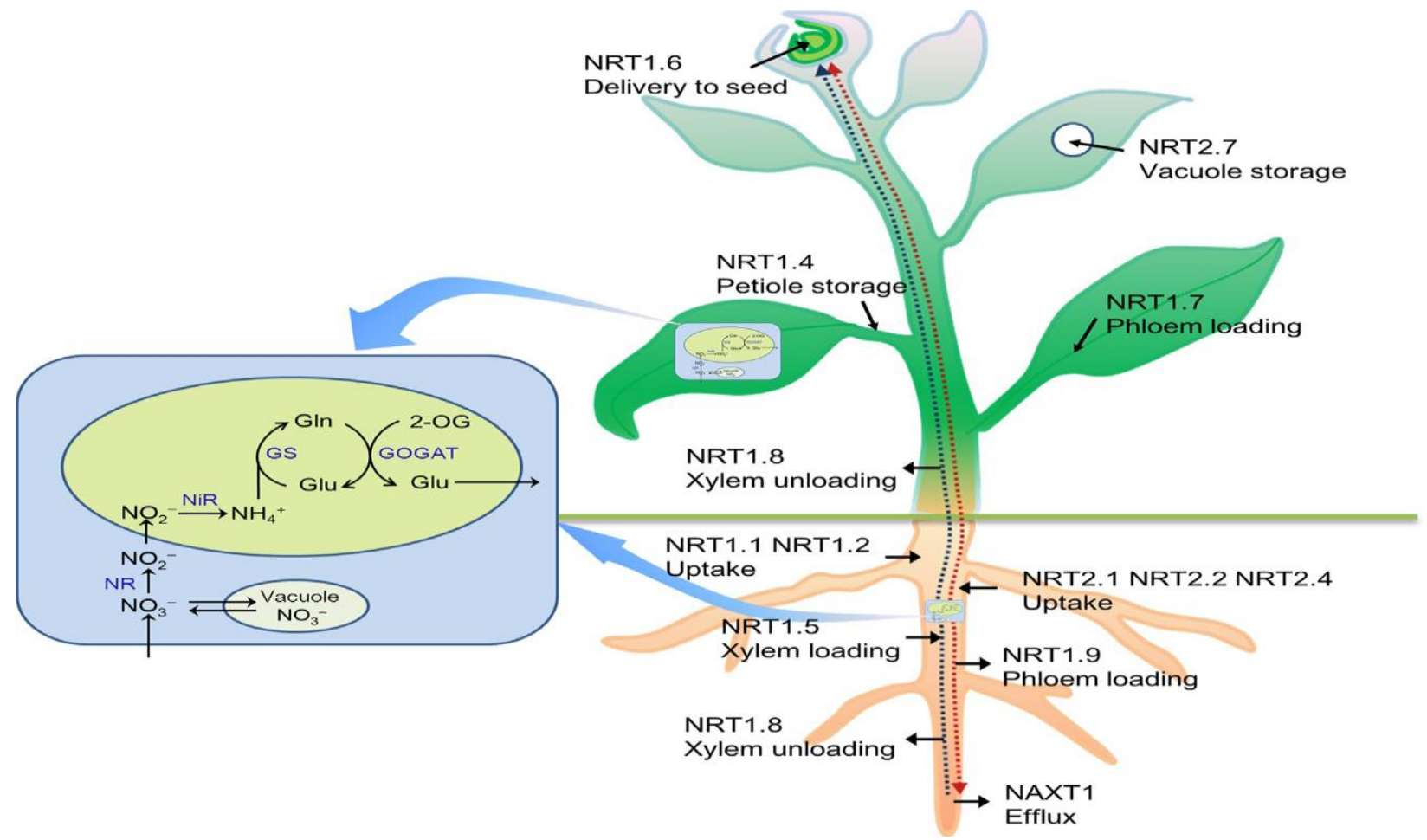

Figure.4 Enzyme pathways important in the balance of $\mathrm{C}$ and $\mathrm{N}$ metabolism. AAT, aspartate amino transferase; AS, asparagine synthetase; GS, glutamine synthetase; GOGAT, glutamate synthase. (Miflin et al., 2002)

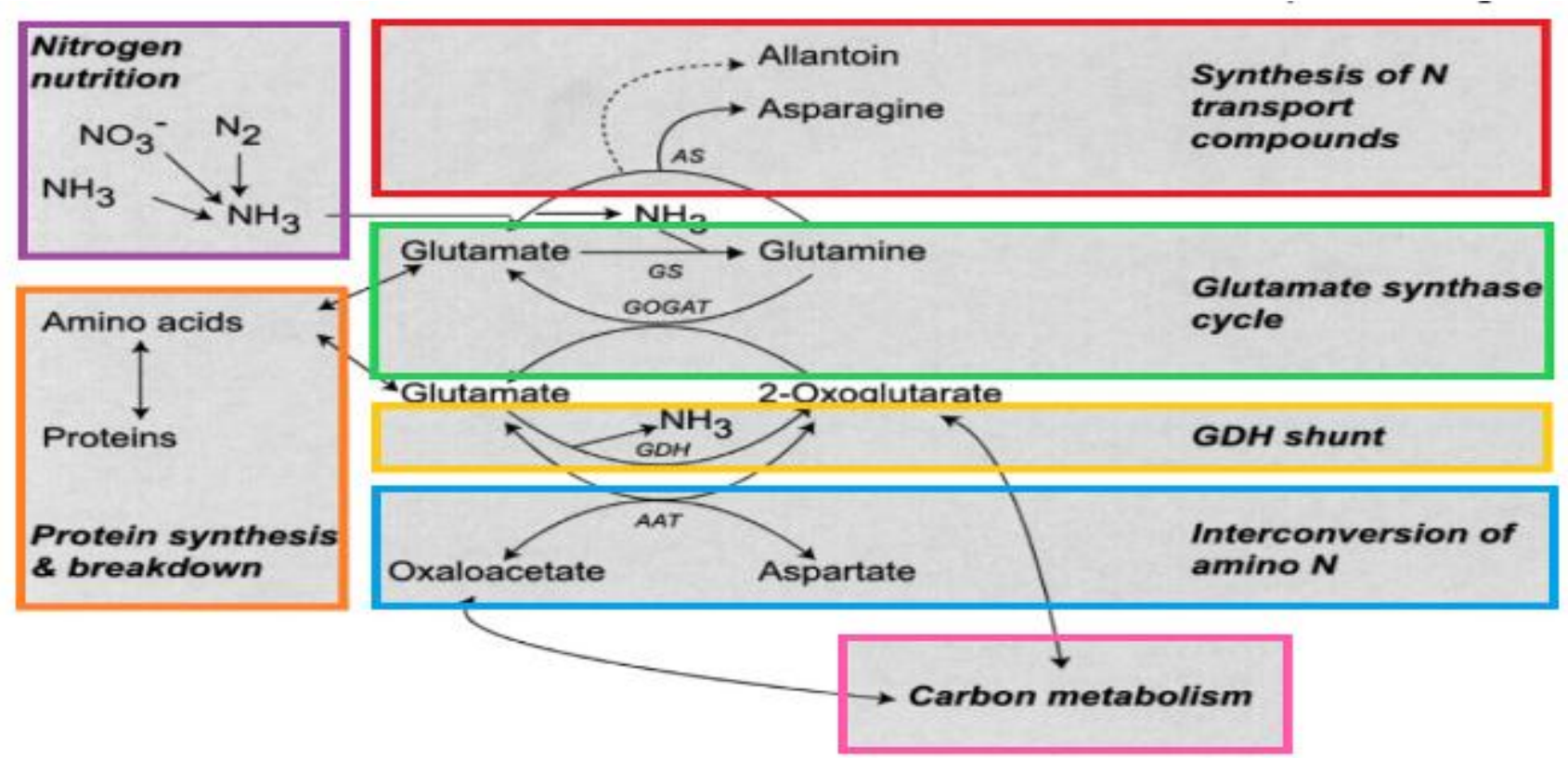


Figure.5 Dof 1 controlling the genes involved in metabolic pathway for nitrogen assimilation in plants. PEP, Phosphoenolpyruvate; OAA, Oxaloacetate; GOGAT, Glutamate synthase; NIA,

Nitrate reductase. (Yanagisawa et al., 2004)

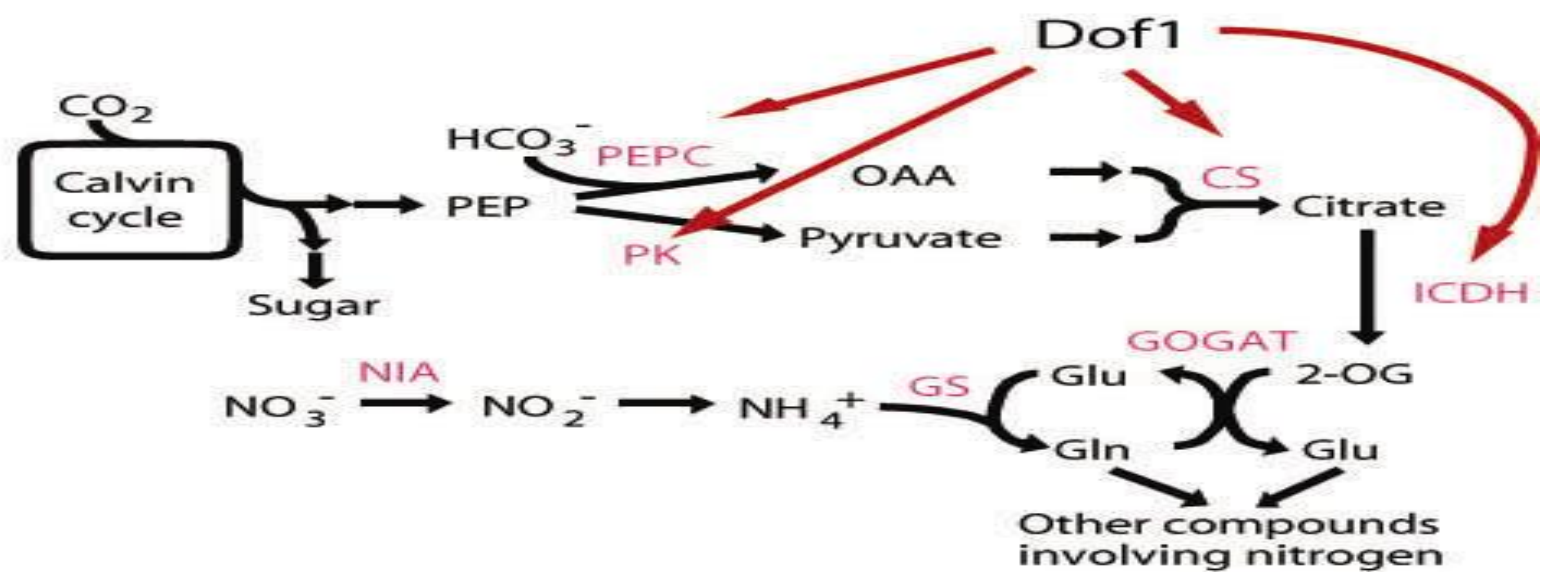

Another transcription factor that has been implicated in NUE is HAP3, a member of protein family haeme activator proteins (HAP). It is involved in regulating flowering time in plants (Cai et al., 2007) and implicated in yeast for increasing NUE (Herna' ndez et al., 2011). In mammalian systems, HAP proteins are also referred to as NF-Y; NF-YB is used to designate HAP3 (Kumimoto et al., 2008). HAP is a protein complex, which also includes HAP2 and HAP5 (Cai et al., 2007). Initial studies on HAP proteins suggested that the overexpression of HAP5a in tomato caused early flowering (Ben-Naim et al., 2006; Cai et al., 2007). However, over-expression of the same protein, as well as HAP3a, in Arabidopsis resulted in delayed flowering (Wenkel et al., 2006; Cai et al., 2007). In yeast the Hap2-3-5-Gln3 complex has been shown to act as a transcriptional activator of both GDH1 and ASN under N-limiting conditions (Herna' ndez et al., 2011), suggesting that plant HAP protein/complexes may interact with $\mathrm{N}$ assimilation enzymes as well.

HY5 and its homolog $\mathrm{HYH}$, two transcription factors from the bZIP family, are essential for phytochrome-dependent light-activated expression of NR (Lillo, 2008). Despite having a negative effect on transcription the NRT1.1 promoter also has three binding sites for HY5 (Lillo, 2008).

PII is an $\mathrm{N}$ sensing and regulatory protein. While a central role for this protein is well documented in bacteria and archaea, its role in $\mathrm{N}$ sensing and signaling in plants is less well understood.

In both Arabidopsis and castor bean, a PIIlike protein / homolog, GLB1, has been studied in relation to its role in $\mathrm{N}$ metabolism. Constitutive over-expression in Arabidopsis of this protein resulted in the accumulation of anthocyanins and a decreased ability to sense or metabolize glutamine (Hsieh et al.,1998). PII also regulates the activity of arginine biosynthesis and may act as a sensor of internal $\mathrm{N}$ levels (Ferrario-Me' ry et al., 2006). In the early to late stages of seed development, Plant PII transcripts have been shown to increase approximately ten-fold, a period in which much of the plant $\mathrm{N}$ is stored as arginine, suggesting a link between PII and protein storage (Uhrig et al., 2009). 
It is concluded that, for economically and environmentally friendly use of valuable $\mathrm{N}$ resources, developing high- NUE cultivars is more challenging than targeting $\mathrm{N}$ applications as part of an integrated nutrient management. So for the production of high NUE crops, we can target several genes either individually or in a combination. There are several individual genes which are being characterized for defining their role in NUE but there is a need for considering such approaches in which two or more genes are analyzed simultaneously but in a combinatorial way. This review presented the enzymes and regulatory processes that can be manipulated for controlling NUE. With regard to the complexity of the challenge we have to face and with regard to the numerous approaches available, the integration of data coming from transcriptomic studies, functional genomics, quantitative genetics, ecophysiology and soil science into explanatory models of whole-plant behavior in the environment have to be encouraged.

Conflict of Interest:

\section{Conflict of Interest}

On behalf of all authors, the corresponding author states that there is no conflict of interest.

\section{References}

Abrol, Y.P., Chatterjee, S.R., Kumar, P.A., and Jain, V. 1999. Improvement in nitrogenous fertilizer utilizationPhysiological and molecular approaches. Curr. Sci. 76: 1357-1364.

Aubert, S., Bligny, R., Douce, R., Ratcliffe, R.G., and Roberts, J.K.M. 2001. Contribution of glutamate dehydrogenase to mitochondrial metabolism studied by $13 \mathrm{C}$ and $31 \mathrm{P}$ nuclear magnetic resonance. J. Exp. Bot. 52: 37-45.

Ben-Naim, O., Eshed, R., Parnis, A., Teper-
Bamnolker, P., Shalit, A., Coupland, G., Samach, A., and Lifschitz, E. 2006. The CCAAT binding factor can mediate interactions between CONSTANS-like proteins and DNA. Plant J. 46: 462-476.

Bernard, S.M., and Habash, D.Z., 2009. The importance of cytosolic glutamine synthetase in nitrogen assimilation and recycling. New Phytologist 182: 608620.

Bi, Y., Kant, S., Clarke, J., Clark, J., Gidda, S., Ming, F., Xu, J., Rochon, A., Shelp, B.J., Hao, L., Zhao, R., Mullen, R.T., Zhu, T., and Rothstein, S.J. 2009. Increased nitrogen-use efficiency in transgenic rice plants overexpressing a nitrogen-responsive early nodulin gene identified from rice expression profiling. Plant Cell Environ. 32: 1749-1760.

Biernath, C., Fischer, H., and Kuzyakov, Y. 2008. Root uptake of N-containing and $\mathrm{N}$-free low molecular weight organic substances by maize. A $14 \mathrm{C} / 15 \mathrm{~N}$ tracer study. Soil Biol. Biochem. 40: 22372245.

Cai, X., Ballif, J., Endo, S., Davis, E., Liang, M., Chen, D., DeWald. D, Kreps. J., Zhu, T., and $\mathrm{Wu}$, Y. 2007. A putative CCAAT-binding transcription factor is a regulator of flowering timing in Arabidopsis. Plant Physiol. 14: 98-105.

Couturier, J., Montanini, B., Martin, F., Brun, A., Blaudez, D., and Chalot, M. 2007. The expanded family of ammonium transporters in the perennial poplar plant. New Phytologist 174: 137-150.

Daniel-Vedele, F., Filleur, S., and Caboche, M. 1998. Nitrate transport: a key step in nitrate assimilation. Current Opinion in Plant Biology 1: 235-239.

David, M., Loubet, B., Cellier, P., Mattson, M., Schjoerring, J.K., Nemitz, E., Roche, R., Riedo, M., and Sutton, M.A. 2009. Ammonia sources and sinks in an intensively managed grassland canopy. Biogeosciences. 6: 1903-1915.

Dechorgnat, J., Nguyen, C.T., Armengaud, P., Jossier, M.J., Diatloff, E., Filleur, S., and Daniel-Vedele, F. 2011. From the 
soil to the seeds: The long journey of nitrate in plants. J. Exp. Bot., 62: 13491359.

Dubois, F., Terce'-Laforgue, T., GonzalezMoro, M.B., Estavillo, M.B., Sangwan, R., Gallais, A., and Hirel, B. 2003. Glutamate dehydrogenase in plants; is there a new story for an old enzyme. Plant Physiol Biochem 41: 565-576

Fernie, A.R., Trethewey, R.N., Krotzky, A., and Willmitzer, L. 2004. Metabolite profiling: From diagnostics to systems biology. Nat. Rev. Mol. Cell Biol. 5: 763-776.

Ferrario-Me' ry, S., Bouvet, M., Leleu, O., Savino, G., Hodges, M., and Meyer, C. 2005. Physiological characterisation of Arabidopsis mutants affected in the expression of the putative regulatory protein PII. Planta, 223: 28-39.

Filleur, S., Walch-Liu, P., Gan, Y., Forde, and B.G., 2005. Nitrate and glutamate sensing by plant roots. Biochem. Soc. Trans. 33: 283-286.

Frink, C.R., Waggoner, P.E., and Ausubel, J.H., 1999. Nitrogen fertilizer: retrospect and prospect. Proceedings of the National Academy of Sciences. 96(4): 11751180.

Gan, S., and Amasino, R.M. 1995. Inhibition of leaf senescence by autoregulated production of cytokinin. Science. 270 (5244): 1986-1988.

Gazzarrini, S., Lejay, L., Gojon, A., Ninnemann, O., Frommer, W.B., and von Wiren, N. 1999. Three functional transporters for constitutive, diurnally regulated, and starvation induced uptake of ammonium into Arabidopsis roots. The Plant Cell 11: 937-947.

Glass, A.D., Britto, D.T., Kaiser, B.N., Kinghorn, J.R., Kronzucker, H.J., Kumar, A., Okamoto, M., Rawat, S., Siddiqi, M.Y., Unkles, S.E., and Vidmar, J.J. 2002. The regulation of nitrate and ammonium transport systems in plants. J. Exp. Bot. 53: 855-864.

Ha“ usler, R.E., Hirsch, H.J., Kreuzaler, F., and Peterha“ nsel, C. 2002. Overexpression of $\mathrm{C}(4)$-cycle enzymes in transgenic $\mathrm{C}(3)$ plants: a biotechnological approach to improve C(3)-photosynthesis. J. Exp. Bot. 53: 591-607.

Herna' ndez, H., Aranda, C., Lo' pez, G., Riego, L., and Gonza' lez, A. 2011. Hap2-3-5-Gln3 determine transcriptional activation of GDH1 and ASN1 under repressive nitrogen conditions in the yeast Saccharomyces cerevisiae. Microbiology 157: 879-889.

Hirel, B. Physiology of maize II (2005) Identification of physiological markers representative of the nitrogen status of maize (Zea mays L.) leaves during grain filling. Physiol. Plant., 124: 178-188.

Hirel, B., Miao, G.H., and Verma, D.P.S. 1993. In Control of Plant Gene Expression. Edited by Verma, D.P.S. pp. 443-458. CRC Press, Inc., Boca Raton, FL, U.S.A.

Hirel, B., Tétu, T., Lea, P.J., and Dubois, F. 2011. Improving Nitrogen Use Efficiency in Crops for Sustainable Agriculture. Sustainability. 3: $1452-$ 1485.

Hsieh, M.H., Lam, H.M., van de Loo, F.J., and Coruzzi, G. 1998. A PII-like protein in Arabidopsis: putative role in nitrogen sensing. PNAS, 95: 13965-13970.

Huynh, L.N., Vantoai, T., Streeter, J., and Banowetz, G. 2005. Regulation of flooding tolerance of SAG12:ipt Arabidopsis plants by cytokinin. J. Exp. Bot. 56: 1397-1407.

Jordi, W., Schapendonk, A., Davelaar, E., Stoopen, G.M., Pot, C.S., De Visser, R., Van Rhijn, J.A., Gan, S., and Amasino, R.M. 2000. Increased cytokinin levels in transgenic PSAG12-IPT tobacco plants have large direct and indirect effects on leaf senescence, photosynthesis and $\mathrm{N}$ partitioning. Plant Cell Environ. 23: 279-289.

Kaiser, W.M., Planchet, E., and Rümer, S. 2011. Nitrate reductase and nitric oxide. In Annual Plant Reviews, Nitrogen Metabolism in Plants in the Postgenomic Era; Foyer, C.H., Zhang, H., 
Eds.; Wiley-Blackwell: Chichester, UK. 42: 127-146.

Keys, A., Bird, I., Cornelius, M., and Lea, P., Wallsgrove, R., Miflin, B. 1978. Photorespiratory nitrogen cycle. Nature 275: 741-743.

Kim, S.A., Kwak, J.M., Jae, S., Wang, M., and Nam, H.G. 2001. Overexpression of the AtGluR2 gene encoding an Arabidopsis homolog of mammalian glutamate receptors impairs calcium utilization and sensitivity to ionic stress in transgenic plants. Plant Cell Physiol. 42: 74-84.

Ku, M.S., Agarie, S., Nomura, M., Fukayama, H., Tsuchida, H., Ono, K., Hirose, S., Toki, S., Miyao, M., and Matsuoka, M. 1999. High-level expression of maize phosphoenolpyruvate carboxylase in transgenic rice plants. Nat. Biotechnol. 17: 76-80.

Kumar, P.A., Parry, M.A.J., Mitchell, R.A.C., Ahmad, A., and Abrol, Y.P. 2001. Photosynthesis and nitrogen use efficiency. In Nitrogen use efficiency. Photosynthetic Nitrogen Assimilation and Associated Carbon Metabolism (eds Foyer, C. H. and Noctor, G.), Advances in Photosynthesis Series, Kluwer, The Netherlands.

Kumimoto, R.W., Adam, L., Hymus, G.J., Repetti, P.P., Reuber, T.L., Marion, C.M., Hempel, F.D., and Ratcliffe, O.J. 2008. The nuclear factor $Y$ subunits NFYB2 and NF-YB3 play additive roles in the promotion of flowering by inductive long-day photoperiods in Arabidopsis. Planta, 228: 709-723.

Kurai, T., Wakayama, M., Abiko, T., Yanagisawa, S., Aoki, N., and Ohsugi, R. 2011. Introduction of the ZmDof1 gene into rice enhances carbon and nitrogen assimilation under low-nitrogen conditions. Plant Biotechnology Journal. 9: 826-37

Kusano, M., Fukushima, A., Redestig, H., and Saito, K. 2011. Metabolomic approaches toward understanding nitrogen metabolism in plants. J. Exp. Bot. 62: 1439-1453.
Labboun, S., Tercé-Laforgue, T., Roscher, A., Bedu, M., Restivo, F.M., Velanis, C.N., Skopelitis, D.S., Moshou, P.N., Roubelakis-Angelakis, K.A., and Suzuki, A. 2009. Resolving the role of plant glutamate dehydrogenase: I. In vivo real time nuclear magnetic resonance spectroscopy experiments. Plant Cell Physiol. 50: 1761-1773.

Lam, H.M., Hsieh, M.H., and Coruzzi, G.M. 1998. Reciprocal regulation of distinct asparagine synthetase genes by light and metabolites in Arabidopsis thaliana. Plant Journal. 16: 345-353.

Lasa, B., Frechilla, S., Aparicio-Tejo, P.M., and Carmen-Lamsfus, C. 2002. Role of glutamate dehydrogenase and phosphoenolpyruvate carboxylase activity in ammonium nutrition tolerance in roots. Plant Physiol Biochem 40: 969-976.

Lea, P.J., and Miflin, B.J. 2011. Nitrogen assimilation and its relevance to crop improvement. In Annual Plant Reviews, Nitrogen Metabolism in Plants in the Post-genomic Era; Foyer, C.H., Zhang, H., Eds.; Wiley-Blackwell: Chichester, UK. 42: 1-40.

Lee, Y.H., Foster, J., Chen, J., Voll, L.M., Weber, A.P., and Tegeder, M. 2007. AAP1 transports uncharged amino acids into roots of Arabidopsis. The Plant Journal 50: 305-319.

Lillo, C. 2008. Signalling cascades integrating light-enhanced nitrate metabolism. Biochemical Journal 415: 11-19.

Lin, C.M., Koh, S., Stacey, G., Yu, S.M., Lin, T.Y., and Tsay, Y.F. 2000. Cloning and functional characterization of a constitutively expressed nitrate transporter gene, OsNTR1, from rice. Plant Physiology 122: 379-388.

Lochab, S., Pathak, R.R., and Raghuram, N. 2007. Molecular approaches for enhancement of nitrogen use efficiency in plants. In Agricultural Nitrogen Use and its Environmental Implications (eds Abrol, Y. P., Raghuram, N. and Sachdev, M. S,), IK International, New 
Delhi. 327-350.

Loussaert, D.F., O’Neill, D., Simmons, C.R. and Wang, H. 2011. Nitrate reductases from red algae, compositions and methods of use thereof. US Patent 20080313775.

Maathuis, F. 2009. Physiological functions of mineral nutrients. Current Opinion in Plant Biology 12: 250-258.

Mae, T. 1997. Physiological nitrogen efficiency in rice: Nitrogen utilization, photosynthesis and yield. In Plant Nutrition for Sustainable Food Production and Environment.51-60.

Makino, A., Shimada, T., Takumi, S., Kaneko, K., Matsuoka, M., Shimamoto, K., Nakano, H., Miyao-Tokutomi, M., Mae, T., and Yamamoto, N. 1997. Does Decrease in Ribulose-I, 5-Bisphosphate Carboxylase by Antisense RbcS Lead to a Higher N-Use Efficiency of Photosynthesis under Conditions of Saturating CO, and Light in Rice Plants. Plant Physiol. 114: 483-91.

Marschner, P. 2012. Marschner's Mineral Nutrition of Higher Plants, third ed. Academic Press, London, Waltham, MA, pp. 135-151.

Martínez, D.E., Costa, M.L., and Guiamet, J.J. $2008 . \quad$ Senescence- associated degradation of chloroplast proteins inside and outside the organelle. Plant Biology. 10: 15-22.

Masclaux-Daubresse, C., Daniel-Vedele, F., Dechorgnat, J., Chardon, F., and Gaufichon, L. 2010. Nitrogen uptake, assimilation and remobilization in plants: challenges for sustainable and productive agriculture. Ann. Bot. 105:1141-57.

Masclaux-Daubresse, C., Quillere, I., Gallais, A., and Hirel, B. 2001. The challenge of remobilization in plant nitrogen economy. A survey of physioagronomic and molecular approaches. Annals of Applied Biology. 138:68-81.

Masle, J., Hudson, G.S., and Badger, M.R. 1993. Effects of ambient $\mathrm{CO}_{2}$ concentration on growth and nitrogen use in tobacco (Nicotiana tabacum) plants transformed with an antisense gene to the small subunit of ribulose-1, 5-bisphosphate carboxylase/oxygenase. Plant Physiology, 103(4), 1075-1088.

McCabe, M.S., Garratt, L.C., Schepers, F., Jordi, W.J., Stoopen, G.M., Davelaar, E., and Davey M.R. 2001. Effects of PSAG12-IPT gene expression on development and senescence in transgenic lettuce. Plant Physiology. 127(2): 505-516

Meyer, C., and Stitt, M. 2001. Nitrate reduction and signalling. In: Lea P, Morot-Gaudry JF, eds. Plant nitrogen. Berlin: Springer Verlag. 37-59

Miflin, B.J., and Habash, D.Z. 2002. The role of glutamine synthetase and glutamate dehydrogenase in nitrogen assimilation and possibilities for improvement in the nitrogen utilization of crops. J. exp. Bot. 53: 979-987.

Miller, A.J., Cookson, S.J., Smith, S.J., and Wells, D.M. 2001. The use of microelectrodes to investigate compartmentation and the transport of metabolized inorganic ions in plants. J. Exp. Bot. 52, 541-549.

Miller, A.J., Fan, X., Orsel, M., Smith, S.J. and Wells, D.M. 2007. Nitrate transport and signaling. J. Exp. Bot. 58, 2297-2306.

Moll, R.H., Kamprath, E.J., and Jackson, W.A. 1982. Analysis and interpretation of factors which contribute to efficiency of nitrogen utilization. Agronomy Journal. 74: 562-564.

Näsholm, T., Huss-Danell, K., and Högberg, P. 2000. Uptake of organic nitrogen in the field by four agriculturally important plant species. Ecology, 81, 1155-1161.

Näsholm, T., Huss-Danell, K., Högberg, P. 2001. Uptake of glycine by field grown wheat. New Phytol. 150: 59-63.

Näsholm, T., Kielland, K., Ganeteg, U. 2009. Uptake of organic nitrogen by plants. New Phytol. 182: 31-48.

Okumoto, S., and Pilot, G. 2011. Amino acid export in plants: a missing link in nitrogen cycling. Mol. Plant. 4:453-63. 
Park, S.Y., Yu, J.W., Park, J.S., Li, J., Yoo, S.C., Lee, N.Y., Lee, S.K., Jeong, S.W., Seo, H.S., Koh, H.J., Jeon, J.S., Park, Y.I., and Paek, N.C. 2007. The senescence-induced staygreen protein regulates chlorophyll degradation. Plant Cell. 19: 1649-1664.

Pathak, R.R., Ahmad, A., Lochab, S., and Raghuram, N. 2008. Molecular physiology of plant $\mathrm{N}$-use efficiency and biotechnological options for its enhancement. Current Science 94(11): 1394-1403.

Price, J., Laxmi, A., Martin, S.K., and Jang, J.C. 2004. Global transcription profiling reveals multiple sugar signal transduction mechanisms in Arabidopsis. Plant Cell. 16: 2128-2150.

Rademacher, T., Häusler, R.E., Hirsch, H.J., Zhang, L., Lipka, V., Weier, D., and Peterhänsel, C. 2002. An engineered phosphoenolpyruvate carboxylase redirects carbon and nitrogen flow in transgenic potato plants. The Plant Journal. 32(1): 25-39.

Raghuram, N., Pathak, R.R., and Sharma, P 2006. Signalling and the molecular aspects of $\mathrm{N}$-use efficiency in higher plants. In Biotechnological Approaches to Improve Nitrogen use Efficiency in Plants (eds Singh, R. P. and Jaiswal, P. K.), Studium Press LLC, Houston, Texas, USA, pp. 19-40.

Reich, P.B., Hobbie, S.E., Lee, T., Ellsworth, D.S., West, J.B., Tilman, D., Knops, J.M.H., Naeem, S., and Trost, J. 2006. Nitrogen limitation constrains sustainability of ecosystem response to CO2. Nature. 440: 922-5.

Rentsch, D., Schmidt, S., and Tegeder, M. 2007. Transporters for uptake and allocation of organic nitrogen compounds in plants. FEBS Lett. 581: 2281-2289.

Rochat, C., and Boutin, J.P. 1991. Metabolism of phloem-borne amino acids in maternal tissues of fruit of nodulated or nitrate-fed pea plants (Pisum sativum L.). Journal of Experimental Botany 42:
207-214.

Rolletschek, H., Hosein, F., Miranda, M., Heim, U., Gotz, K.P., Schlereth, A., Borisjuk, L., Saalbach, I., Wobus, U., and Weber, H. 2005. Ectopic expression of an amino acid transporter (VfAAP1) in seeds of Vicia narbonensis and pea increases storage proteins. Plant Physiol. 137: 1236-1249.

Salsac, L., Chaillou, S., Morot-Gaudry, J.F., Lesaint, C., and Jolivet, E. 1987. Nitrate and ammonium nutrition in plants. Plant Physiol. Biochem. 25: 805-812.

Sato, T., Maekawa, S., Yasuda, S., Domeki, Y., Sueyoshi, K., Fujiwara, M., and Yamaguchi, J. 2011. Identification of 14- 3- 3 proteins as a target of ATL31 ubiquitin ligase, a regulator of the $\mathrm{C} / \mathrm{N}$ response in Arabidopsis. The Plant Journal. 68(1): 137-146.

Scheible, W.R., Gonzalez-Fontes, A., Lauerer, M., Muller-Rober, B., Caboche, M., and Stitt M. 1997. Nitrate acts as a signal to induce organic acid metabolism and repress starch metabolism in tobacco. Plant Cell. 9: 783-798.

Schofield, R.A., Bi, Y.M., Kant, S., and Rothstein, S.J. 2009. Over-expression of STP13, a hexose transporter, improves plant growth and nitrogen use in Arabidopsis thaliana seedlings. Plant Cell Environ. 32: 271-285.

Sétif, P., Hirasawa, M., Cassan, N., Lagoutte, B., Tripathy, J.N., and Knaff, D.B. 2009. New insights into the catalytic cycle of plant nitrite reductase. Electron transfer kinetics and charge storage. Biochemistry. 48: 2828-2838.

Skopelitis, D., Paranychianakis, N., Paschalidis, K., Pliakonis, E., Delis, I., Yakoumakis, D., Kouvarakis, A., Papadakis, A., Stephanou, E., and RoubelakisAnfelakis, K. 2006. Abiotic stress generates ROS that signal expression of anionic glutamate dehydrogenases to form glutamate for proline synthesis in tobacco and grapevine. Plant Cell 18: 2767-2781.

Socolow, R.H. 1999. Nitrogen management and 
the future of food: lessons from the management of energy and carbon. Proceedings of the National Academy of Sciences. 96(11): 6001-6008.

Stitt, M., Müller, C., Matt, P., Gibon, Y., Carillo, P., Morcuende, R., Sheible, W.R., and Krapp, A. 2002. Steps towards an integrated view of nitrogen metabolism. J. Exp. Bot. 53: 959-970.

Suzuki, Y., Ohkubo, M., Hatakeyama, H., Ohashi, K., Yoshizawa, R., Kojima, S., Hayakawa, T., Yamaya, T.T.M and Makino, A. 2007. Increased Rubisco content in transgenic rice transformed with the "Sense" rbcS Gene. Plant Cell Physiol. 48: 626-637.

Taylor, L., Nunes-Nesi, A., Parsley, K., Leiss, A., and Leach G. 2010. Cytosolic pyruvate, orthophosphate dikinase functions in nitrogen remobilization during leaf senescence and limits individual seed growth and nitrogen content. Plant J. 62:641-52

Terce-Laforgue, T., Mack, G., and Hirel, B. 2004. New insights towards the function of glutamate dehydrogenase revealed during sorce sink transition of tobacco (Nicotiana tabacum) plants grown under different nitrogen regimes. Physiol. Plant. 120, 220-228.

Tsay, Y.F., Chiu, C.C., Tsai, C.B., Ho, C.H., and Hsu, P.K. 2007. Nitrate transporters and peptide transporters. FEBS Letters 581: 2290-2300.

Uauy, C., Distelfeld, A., Fahima, T., Blechl, A., and Dubcovsky, J. 2006. A NAC gene regulating senescence improves grain protein, zinc, and iron content in wheat. Science. 314:1298-1301.

Uhrig, R.G., Ng, K.K.S., and Moorhead, G.B.G. 2009. PII in higher plants: a modern role for an ancient protein. Trends Plant Sci. 14: 505-511.

Unno, H., Uchida, T., and Sugawara, H. 2006. Atomic structure of plant glutamine synthetase: a key enzyme for plant productivity. Journal of Biological Chemistry 281: 29287-29296.

Vanoni, M., Dossena, L., van den Heuvel, R.,
Curti, B. 2005. Structure-function studies on the complex iron-sulfur flavoprotein glutamate synthase: the key enzyme of ammonia assimilation. Photosynthesis Research 83: 219-238.

Vitousek, P.M., Naylor, R., Crews, T., Davi, M.B., Drinkwater, L.E., Holland, E., Johnes, P.J., Katzenberger, J., Martinelli, L.A., Matson, P.A., Nziguheba, G., Ojima, D., Palm, C.A., Robertson, G.P., Sanchez, P.A., Townsend, A.R., and Zhang, F.S. 2009. Nutrient imbalances in agricultural development. Science. 324: 1519-1520.

Wang, M., Shen, Q., Xu, G., and Guo, S. 2014. New Insight into the Strategy for Nitrogen Metabolism in Plant Cells. International Review of Cell and Molecular Biology. 310:1-37

Wang, R., Liu, D., and Crawford, N.M. 1998. The Arabidopsis CHL1 protein plays a major role in high-affinity nitrate uptake. Proc. Natl. Acad. Sci. U. S. A. 95: 15134-15139.

Ward, M., Grimes, H., Huffaker, R. 1989. Latent nitrate reductase activity is associated with the plasma membrane of corn roots. Planta. 177: 470-475.

Wenkel, S., Turck, F., Singer, K., Gissot, L., Le Gourrierec, J., Samach, A., and Coupland, G. 2006. CONSTANS and the CCAAT box binding complex share a functionally important domain and interact to regulate flowering of Arabidopsis. Plant Cell. 18: 2971-2984.

Williams, L., and Miller, A. 2001. Transporters responsible for the uptake and partitioning of nitrogenous solutes. Annual Review of Plant Physiology and Plant Molecular Biology 52: 659-688.

Wirth, J., Chopin, F., and Santoni, V., 2007. Regulation of root nitrate uptake at the NRT2.1 protein level in Arabidopsis thaliana. Journal of Biological Chemistry 282: 23541-23552.

Yakoumakis, D., Kouvarakis, A., Papadakis, A., Stephanou, E., Roubelakis-Anfelakis, K. 2006. Abiotic stress generates ROS that signal expression of anionic glutamate 
dehydrogenases to form glutamate for proline synthesis in tobacco and grapevine. Plant Cell. 18: 2767-2781.

Yanagisawa, S., Akiyama, A., Kisaka, H., Uchimiya, H., and Miwa, T. 2004. Metabolic engineering with Dof1 transcription factor in plants: improved nitrogen assimilation and growth under low-nitrogen conditions. PNAS. 101, 7833-7838.

Yuan, L., Loque, D., Ye, F., Frommer, W.B., and von Wiren, N. 2007. Nitrogendependent posttranscriptional regulation of the ammonium transporter AtAMT1;1. Plant Physiology. 143: 732744.

Zhang, H., and Forde, B.G. 1998. An Arabidopsis MADS box gene that controls nutrient-induced changes in root architecture. Science, 279(5349): 407-409.

Zheng, Z.L. 2009. Carbon and nitrogen nutrient balance signaling in plants. Plant Signaling \& Behavior. 4: 584-91.

\section{How to cite this article:}

Anamika Kashyap, Arnab Saha, I.N. Sanyal and Singh, B.R. 2018. Concurrent Expression and Regulation of Genes Involved in Carbon and Nitrogen Metabolism in Relation with Nitrogen Use Efficiency. Int.J.Curr.Microbiol.App.Sci. 7(07): 1894-1909.

doi: https://doi.org/10.20546/ijcmas.2018.707.225 